\title{
DEVELOPMENT AND VALIDATION OF A HEALTH RELATED QUALITY OF LIFE QUESTIONNAIRE FOR BRAZILIAN CHILDREN WITH EPILEPSY
}

\author{
Preliminary findings
}

\author{
Heber de Souza Maia Filho', Marleide da Mota Gomes², \\ Lucia Maria da Costa Fontenelle ${ }^{3}$
}

\begin{abstract}
Purpose: To construct a multidimensional questionnaire that analyses the epileptic child quality of life from the parental point of view. Method: The pilot questionnaire was composed of 157 questions distributed in several dimensions. Fifty-one epileptic children's parents answered the questionnaire. The instrument was tested in its diverse properties: frequency of endorsement, homogeneity (Cronbach alpha), criterion and face validity, and later it was reduced. Results: Endorsement frequency excluded 65 questions that did not attain a minimum of $5 \%$ response per item. Cronbach alpha was as follows: physical (0.93), psychological (0.91), social (0.91), familiar (0.70), cognitive (0.92), medical (0.30) and economical (0.37). Patient groups, in relation to seizure control, significantly differed only in physical domain and total score, although there was a trend to differences in other domains. The final questionnaire (QVCE50) has 50 items, with good homogeneity in the physical, psychological and cognitive domains. Conclusion: QVCE-50 is a promissing Brazilian HRQL questionnaire for children with epilepsy.It needs to be applied in a larger population to confirm its psychometric properties.
\end{abstract}

KEY WORDS: quality of life, epilepsy, childhood, adolescence.

\begin{abstract}
Con s trução e validação de um questionário de qualidade de vida relacionada à saúde para crianças brasileiras com epilepsia: resultados preliminares

RESUMO - Objetivo: Construir um questionário multidimensional analisando a qualidade de vida da criança com epilepsia do ponto de vista dos responsáveis. Método: O questionário piloto foi composto de 157 itens distribuídos em várias dimensões. Cinqüenta e um responsáveis de crianças com epilepsia responderam ao questionário. $O$ instrumento foi testado em suas diversas propriedades freqüência de endosso, homogeneidade (alfa de Cronbach), validade de critério e aparência, sendo posteriormente reduzido. Resultados: A freqüência de endosso excluiu 65 questões que não atingiram um mínimo de $5 \%$ de respostas por item. O alfa de Cronbach foi: domínio físico $(0,93)$, psicológico $(0,91)$, social $(0,91)$, familiar $(0,70)$, cognitivo $(0,92)$, médico $(0,30)$ e econômico $(0,37)$. Os grupos de pacientes (de acordo com o controle de crises) diferiram significativamente apenas no domínio físico e no escore total, embora seja percebida uma tendência à diferença nos demais domínios. O questionário final (QVCE50) tem 50 itens, com boa homogeneidade nos domínios físico, psicológico e cognitivo. Conclusão: O QVCE-50 é um questionário de qualidade de vida relacionada á saúde promissor. Há necessidade de aplicá-los a uma população maior a fim de testar suas características psicométricas.
\end{abstract}

PALAVRAS-CHAVE: qualidade de vida, epilepsia, criança, adolescente.

Any chronic disease poses threatens to a child's physical, psychological, social and cognitive development ${ }^{1,2}$. Epilepsy seems to affect children more than other chronic diseases such as asthma ${ }^{3}$. Some aspects that add to poor quality of life in epilepsy include disease characteristics (etiology, seizure fre- quency, collateral effects of anti epileptic drugs or surgery, risk of accidents), psychological consequences (personal and parental concerns, feelings of guilt and rejection, personality development) social insertion (limitations at work and leisure time) and educational achievement (school performance and

\footnotetext{
${ }^{1}$ Neuropediatrician, Assistant Professor, Department of Maternal and Child Health, Faculdade de Medicina de Petrópolis, Postgraduation (Doctorate), Institute of Psychiatry / Federal University of Rio de Janeiro, Rio de Janeiro RJ, Brazil (UFRJ); ${ }^{2}$ Neurologist, Associate Professor, Institute of Neurology, UFRJ; ${ }^{3}$ Neuropediatrician, Associate Professor, Institute of Pediatrics, UFRJ.
}

Received 14 August 2004, received in final form 4 January 2005. Accepted 27 January 2005.

Dr. Heber S. Maia Filho - Rua 16 de Março $102 / 203$ - 25620-040 Petrópolis RJ - Brasil. E-mail: heber@redetaho.com.br 
vocational issues $)^{4}$. It is essential that a modern epilepsy approach recognize the influence of these factors on disease control and children's well being. Successful treatment should not be measured only by seizu recontrol, but also by quality of life impro v ement ${ }^{4,5}$. Quality of life has been deeply studied in the epilepsy field. Health related quality of life (HRQL) is a multidimensional construct that deals with one person's perceptions about disease's burden at several dimensions of life (physical, psychosocial, cognitive, work).

There are many HRQL instruments for epileptic adults, with defined validity and reliability. Some of them have already been translated into the Portuguese language ${ }^{5-9}$. Generic and qualitative measu res have also been published ${ }^{10-14}$. These instruments can be applied on research (population studies, drug trials and clinical outcome after drug or surg ical treatment) and clinical settings. There is comparably limited researh dealing with HRQL of epileptic children. Methodological issues are a particular limitation since parental perception, the child's own opinion and developmental changes are to be dealt with $^{15}$. There are a number of studies of individual aspects of HRQL in epileptic children ${ }^{16-23}$ but few with a multidimensional approach ${ }^{22-27}$. Only Sabaz and col. ${ }^{22}$ describe methodological aspects of validity and reliability. Their study is limited to refractory epilepsy. Because of the high prevalence of epilepsy in children, it's important to make specific instruments for them, especially in developing countries where living with epilepsy is an additional problem that limits one's growing and social development.

The aims of this study were: 1 . To develop a Portuguese instrument that evaluates HRQL of the epileptic child in its physical, psychological, social/familiar and cognitive/educational domains from the familiar point of view. 2 . To define instrument validity.

\section{METHOD}

Development of the pilot questionnaire - The construct utilized was "health related quality of life". It implies in asking the patient (at this case, the family) about the perceived state of well being and the impact of the disease (epilepsy) at several domains. We emphasized the aspects of quality of life that can be modified by medical decision or health polices, not including social (structural, economical aspects) and environmental issues that, although pertinent to the WHO conceptualization, are less manageable by clinical action ${ }^{1}$ and that refers to the entire population and not specifically to the patient. In spite of this first consideration, we decided to include, experimentally, an economic and a medical assistance domain (doctor-patient relationship) due to the socioeconomic characteristics of Brazil. The

Appendix 1. Pilot questionnaire content.

\begin{tabular}{ll}
\hline $\begin{array}{l}\text { Physical domain } \\
\text { Children care }\end{array}$ & $\begin{array}{l}\text { Familiar domain } \\
\text { Relationships }\end{array}$ \\
$\begin{array}{l}\text { Leisure time } \\
\text { Sports }\end{array}$ & $\begin{array}{l}\text { Shame because of the disease } \\
\text { Guilt because of disease } \\
\text { Restrictions to physical activity }\end{array}$ \\
$\begin{array}{l}\text { Self care } \\
\text { Transport utilization }\end{array}$ & $\begin{array}{l}\text { Job limitations and family plans } \\
\text { restrictions }\end{array}$ \\
$\begin{array}{l}\text { Accidents } \\
\text { Physical pain }\end{array}$ & Family happiness \\
Energy and vitality & Cognitive / educational domain \\
Sleep & School achievement, attendance and behavior \\
Side effects of antiepileptic drugs & Cognition (memory, attention, comprehension, \\
Seizure frequency perception & language, reading, arithmetic) \\
Seizure characteristics & \\
Help at seizure time & Medical assistance domain \\
Necessity of urgent medical visits or & Doctor-patient relationship \\
hospitalization & \\
& Economical domain \\
Psychological domain & Economical aspects (access to medications \\
Feelings & and attendance to medical visit) \\
Fear of accident or death & \\
Behavior & General domain \\
Social domain & Perception of health and quality of life \\
Social prejudice & Future expectations \\
Restrictions to social activities & \\
Social knowledge about disease & \\
\hline
\end{tabular}


questionnaire was answered by the person responsible for the child. Items have four possible answers, scored one to four. Domains were equally weighted by means of per cent scores. Items have been built from previous scales consultation (adaptation and translation with authorization), bibliographical revision of theoretical basis of the domains and the authors' clinical experience. Appendix shows item description utilized ${ }^{7,16-19,22,24,27-35}$. Items were critically reviewed in terms of complexity, ambiguity, jargons, moral judgments and negative feelings. Some items, then, have been modified or discharted. The content and face validity have been taken into consideration. The pilot questionnaire contained 157 questions, divided into physical domain (47), psychological domain (51), social (11) and familiar (13) domains, cognitive/educational (28) domain, medical assistance (2) and economic (2) domains, plus 3 general questions about quality of life. The questionnaire ended with a quality of life scale scored 0 to 10 , and a space for free observations.

Pilot questionnaire application - The pilot sample included 51 epileptic children families consecutively seen at the Neuropediatrics services of the Institute of Pediatrics/ Universidade Federal do Rio de Janeiro (42 - 82.3\%) and Faculdade de Medicina de Petrópolis (9 - 17.7\%). This study was approved by the Ethical Committee of IPP$M G / U F R J$, process $23 / 01$. The eligibility criteria were: age between six and 16 years-old; epilepsy diagnosis according to ILAE ${ }^{36,37}$; minimum of 6 months of disease and regular medical assistance, school attendance and direct caregiver present at the moment of the interview. Serious physical disability or mental retardation ${ }^{38}$ we reexcluded.

Pilot questionnaire analysis and reduction - We applied the frequency of endorsement (minimum of 0.05) as an indicative of item importance, and the Cronbach's alpha (minimum of 0.70 ), and the total-item correlation ( $\mathrm{m}$ in imum of 0.20 ), as domain homogeneity indicators ${ }^{39}$. After items had been discarded by these criteria, alpha in the psychological and cognitive/educational domains was still high, allowing domain reduction by qualitative means (less intelligible or similar items). The final result was a 50-item questionnaire (QVCE-50: "quality of life of the epileptic child" in Portuguese - 50 items), with the following distribution in the domains: physical (14), psychological (37), social/familiar (7), cognitive/educational (23). The criteria validity was also tested by comparing per cent scores of three different seizure groups

Table 1. Per cent scores and seizure control - Pilot questionnaire.

\begin{tabular}{|c|c|c|c|c|c|}
\hline Score $(\%)$ & Total & Controlled & Few seizures & Intractable & $\mathrm{P}$ \\
\hline Physical & $\begin{array}{l}83.5 \\
\text { CI } 80.34 / 86.66 \\
\text { SD } 11.5\end{array}$ & $\begin{array}{l}88.9 \\
\text { CI } 84.90 / 92.90 \\
\text { SD } 8.9\end{array}$ & $\begin{array}{l}81.6 \\
\text { CI } 77.45 / 85.75 \\
\text { SD } 10.8\end{array}$ & $\begin{array}{l}74.1 \\
\text { CI } 61.94 / 86.26 \\
\text { SD } 15.2\end{array}$ & 0.01 \\
\hline Psychological & $\begin{array}{l}76.8 \\
\text { Cl } 73.73 / 79.87 \\
\text { SD } 11.2\end{array}$ & $\begin{array}{l}78.9 \\
\text { CI } 73.91 / 83.89 \\
\text { SD } 11.1\end{array}$ & $\begin{array}{l}76.4 \\
\text { CI } 72.29 / 80.51 \\
\text { SD } 10.7\end{array}$ & $\begin{array}{l}73.3 \\
\text { CI } 61.94 / 84.66 \\
\text { SD } 14.2\end{array}$ & 0.54 \\
\hline Social & $\begin{array}{l}85.7 \\
\text { CI } 80.87 / 90.53 \\
\text { SD } 17.6\end{array}$ & $\begin{array}{l}85.6 \\
\text { CI } 77.69 / 93.51 \\
\text { SD } 17.6\end{array}$ & $\begin{array}{l}89.1 \\
\text { CI } 83.56 / 94.64 \\
\text { SD } 14.4\end{array}$ & $\begin{array}{l}71.2 \\
\text { CI } 50.88 / 91.52 \\
\text { SD } 25.4\end{array}$ & 0.08 \\
\hline Familiar & $\begin{array}{l}84.6 \\
\text { CI } 80.84 / 88.36 \\
\text { SD } 13.7\end{array}$ & $\begin{array}{l}82.7 \\
\text { CI } 74.79 / 90.61 \\
\text { SD } 17.6\end{array}$ & $\begin{array}{l}87.3 \\
\text { CI } 83.26 / 91.34 \\
\text { SD } 10.5\end{array}$ & $\begin{array}{l}78.8 \\
\text { CI } 70.08 / 87.52 \\
\text { SD } 10.9\end{array}$ & 0.3 \\
\hline Educational & $\begin{array}{l}76.9 \\
\text { Cl } 72.70 / 81.10 \\
\text { SD } 15.3\end{array}$ & $\begin{array}{l}81.5 \\
\text { CI } 74.53 / 88.47 \\
\text { SD } 15.5\end{array}$ & $\begin{array}{l}75.7 \\
\text { CI } 69.93 / 81.47 \\
\text { SD } 15.0\end{array}$ & $\begin{array}{l}67.4 \\
\text { CI } 57.24 / 77.56 \\
\text { SD } 12.7\end{array}$ & 0.12 \\
\hline Medical & $\begin{array}{l}96.6 \\
\text { Cl } 94.13 / 99.07 \\
\text { SD } 9.0\end{array}$ & $\begin{array}{l}97.4 \\
\text { CI } 93.40 / 100 \\
\text { SD } 8.9\end{array}$ & $\begin{array}{l}97.6 \\
\text { CI } 95.29 / 99.91 \\
\text { SD } 6.0\end{array}$ & $\begin{array}{l}89.5 \\
\text { CI } 76.22 / 100.0 \\
\text { SD } 16.6\end{array}$ & 0.12 \\
\hline Economical & $\begin{array}{l}68.4 \\
\text { Cl } 61.57 / 75.23 \\
\text { SD } 24.9\end{array}$ & $\begin{array}{l}73.7 \\
\text { CI } 62.95 / 84.45 \\
\text { SD } 23.9\end{array}$ & $\begin{array}{l}67.3 \\
\text { CI } 57.88 / 76.72 \\
\text { SD } 24.5\end{array}$ & $\begin{array}{l}56.2 \\
\text { Cl } 32.84 / 79.56 \\
\text { SD } 29.2\end{array}$ & 0.31 \\
\hline General & $\begin{array}{l}77.7 \\
\text { CI } 72.84 / 82.56 \\
\text { SD } 17.7\end{array}$ & $\begin{array}{l}80.3 \\
\text { CI } 70.36 / 90.24 \\
\text { SD } 22.1\end{array}$ & $\begin{array}{l}78.1 \\
\text { CI } 73.37 / 82.83 \\
\text { SD } 12.3\end{array}$ & $\begin{array}{l}68.0 \\
\text { CI } 50.40 / 85.60 \\
\text { SD } 22.0\end{array}$ & 0.33 \\
\hline Total & $\begin{array}{l}80.5 \\
\text { Cl } 77.81 / 83.19 \\
\text { SD } 9.8\end{array}$ & $\begin{array}{l}83.7 \\
\text { CI } 80.06 / 87.34 \\
\text { SD } 8.1\end{array}$ & $\begin{array}{l}80.0 \\
\text { CI } 7631 / 83.69 \\
\text { SD } 9.6\end{array}$ & $\begin{array}{l}72.4 \\
\text { CI } 63.12 / 81.68 \\
\text { SD } 11.6\end{array}$ & 0.04 \\
\hline
\end{tabular}

$\mathrm{Cl}$, confidence interval; SD, standard deviation. 
Table 2. Per cent scores and seizure control - QVCE-50.

\begin{tabular}{|c|c|c|c|c|c|}
\hline Score $(\%)$ & Total & Control & Few seizures & Intractable & $\mathrm{P}$ \\
\hline Physical & $\begin{array}{l}76.3 \\
\text { Cl } 67.59 / 85.01 \\
\text { SD } 14.05\end{array}$ & $\begin{array}{l}89.2 \\
\text { Cl } 87.85 / 90.55 \\
\text { SD } 2.18\end{array}$ & $\begin{array}{l}69.4 \\
\text { Cl } 63.75 / 75.05 \\
\text { SD } 10.4\end{array}$ & $\begin{array}{l}56.9 \\
\text { Cl } 42.29 / 70.51 \\
\text { SD } 9.82\end{array}$ & $p<0.001$ \\
\hline Psychological & $\begin{array}{l}77.2 \\
\text { CI } 70.69 / 83.71 \\
\text { SD } 10.5\end{array}$ & $\begin{array}{l}78.0 \\
\text { Cl } 71.62 / 84.38 \\
\text { SD } 10.30\end{array}$ & $\begin{array}{l}77.1 \\
\text { CI } 70.94 / 83.26 \\
\text { SD } 11.34\end{array}$ & $\begin{array}{l}73.6 \\
\text { CI } 57.27 / 89.93 \\
\text { SD } 11.78\end{array}$ & 0.87 \\
\hline Social/familiar & $\begin{array}{l}85.6 \\
\text { CI } 78.77 / 92.43 \\
\text { SD } 11.02\end{array}$ & $\begin{array}{l}90.0 \\
\text { CI } 85.13 / 94.87 \\
\text { SD } 7.86\end{array}$ & $\begin{array}{l}81.3 \\
\text { CI } 74.53 / 88.07 \\
\text { SD } 12.46\end{array}$ & $\begin{array}{l}91.07 \\
\text { Cl } 87.58 / 94.56 \\
\text { SD } 2.52\end{array}$ & 0.12 \\
\hline Cognitive-Educational & $\begin{array}{l}78.2 \\
\text { CI } 68.27 / 88.13 \\
\text { SD } 16.02\end{array}$ & $\begin{array}{l}84.7 \\
\text { Cl } 78.32 / 91.08 \\
\text { SD } 10.30\end{array}$ & $\begin{array}{l}75.1 \\
\text { Cl } 64.83 / 85.37 \\
\text { SD } 18.90\end{array}$ & $\begin{array}{l}66.4 \\
\text { CI } 52.62 / 80.18 \\
\text { SD } 9.94\end{array}$ & 0.20 \\
\hline Total & $\begin{array}{l}78.6 \\
\text { CI } 72.36 / 84.84 \\
\text { SD } 10.06\end{array}$ & $\begin{array}{l}83.8 \\
\text { CI } 78.74 / 88.86 \\
\text { SD } 8.16\end{array}$ & $\begin{array}{l}75.7 \\
\text { Cl } 70.07 / 81.33 \\
\text { SD } 10.36\end{array}$ & $\begin{array}{l}70.7 \\
\text { Cl } 62.37 / 79.03 \\
\text { SD } 6.01\end{array}$ & 0.07 \\
\hline
\end{tabular}

$\mathrm{Cl}$, confidence interval; SD, standard deviation.

Table 3. Reduction of the pilot questionnaire.

\begin{tabular}{|c|c|c|c|c|c|}
\hline Domains & Remaining items & Conbrach's alpha & $\begin{array}{c}\text { More items } \\
\text { excluded }\end{array}$ & Total end & $\begin{array}{c}\text { Final Conbrach's } \\
\text { alpha }\end{array}$ \\
\hline Physical & 14 & 0.75 & $5^{*}$ & 9 & 0.75 \\
\hline Psychological & 37 & 0.90 & $19 * *$ & 18 & 0.86 \\
\hline Social/ familiar & 7 & 0.60 & - & 7 & 0.60 \\
\hline Cognitive/educational & 23 & 0.93 & $7 * * *$ & 16 & 0.88 \\
\hline Total & 81 & - & 19 & 50 & - \\
\hline
\end{tabular}

* Items about side effects were grouped in a single question about side effect frequency. ** Items excluded were those about similar feelings, negative value or of difficult understanding. *** Items that specified diff e rent levels of attention, memory and understanding were reduced to single questions, since parents didn't understand them.

(seizurefree, few seizures - less than 10 per year, uncontrolled seizures), searching for significant decrease in HRQL with worse seizure control $(p<0.05)$.

Final questionnaire application - QVCE-50 was sent by mail to 31 of the 51 original families who had up to date addresses. Only 25 questionnaires were sent back. The same member of the family answered the second questionnaire.

Validity of the final questionnaire - Cronbach's alpha, total-item correlation and criterion validity were applied to QVCE-50.

\section{RESULTS}

Age of patients varied from six to 16 years old (mean $10 \pm 3$ years), with 27 females (52.9\%) and 24 males (47.1\%). Twenty-one were Caucasians $(41.2 \%), 16$ blacks (31.4\%) and 14 interracial (27.5\%). Forty-nine patients (94.2\%) were from low income. Four $(7.8 \%)$ patients had slight mental retardation and $2(3.9 \%)$, discrete hemi paresis. Nineteen questionnaires (37.3\%) were dictated, and $32(62.7 \%)$ were self-answered. The responders were the mother (43-84.3\%), father (4-7.8\%), grandmother (3-5.9\%) or both parents (1-2.0\%). All children and adolescents were regularly going to school.

Epilepsy duration was six years in mean. Twenty (39.3\%) had focal seizures, $6(11.7 \%)$ focal seizure s with secondary generalization and $25(50 \%)$ primary generalized seizures. Thirty-five $(68.6 \%)$ of the epilepsies were idiopathic. Nineteen (37.3\%) children were seizure free, $26(51 \%)$ had few seizures and six (11.8\%) intractable seizures. Forty-five patients were in monotherapy and $2(3.9 \%)$, temporarily without drugs.

Percent scores of the pilot and final questionnaires are shown at Table 1 and 2, as well as score differences between groups of seizure control. Statistical analysis and the reduction process are shown in Table 3.

\section{DISCUSSION}

Development and application of the pilot ques tionnaire - Developing an HRQL instrument implies 
attaining several stages of quality, allowing its validity in describing and quantifying the biopsychosocial well being of a given population ${ }^{4}$. The instrument must be broad and specific to the disease; even though generic instruments have their value. It must be quantitative, permitting standard application and reliability. The construct validity of a questionnaire depends on the exact definition of quality of life used. We opted for the health related quality of life definition, because it is related to aspects in which health professionals may interfere. The trial of including economical and assistance aspects has not proven to be efficacious (low frequency of endorsement). We decided to abandon these items in the final questionnaire, although they a re important as far as public health is concerned.

Deciding for the parent view is also controversial. We took into consideration that the perception of health and disease matures with age and is dif$f$ e rent across stages of life ${ }^{16,40-42}$. It would be necessary a different questionnaire for each age, but that would be difficult at this stage of instrument development. It seems that biases are more present when proxies are answering for adult patients. Parents give more adequate responses about functional characteristics than subjective ones, like personal feelings and familiar dynamics ${ }^{43}$. This may be a possible explanation why the physical domain is the only one to attain criteria validity, when comparing different levels of seizure control.

The number of patients chosen were according to literature orientation about samples for questionnaire construction ${ }^{39}$. We had difficulty increasing samples because of the rigid criteria selection, since the terc i a ryservices we perf o rmed had a significant number of intractable epilepsy patients with mental re $t$ a rdation and motor handicaps. Patients without these problems are generally idiopathic epilepsy ones. This artificial manipulation was necessaryin the questionnaire construction. In practice, a physician must take into account all patients problems concerning quality of life.

The total number of items must be a limiting factor in the quality of the responses. In the initial stage, it was essential to have the greatest number of items possible, attaining content validity. We revised all questionnaires for missed answers. Few parents answered the free spaces, probably because of exhaustion after answering the objective part. Another important factor was the necessity of simplifying the content of questions because of the low scholarship of parents. Quality of life questionnaires suffer transcultural variations and a simple translation is not always appropriate ${ }^{39}$. The richness of details in some questions of original instruments was lost in order to make them more understandable to a poor educated population. This instrument is valid for public health services of neuropediatrics in developing countries where Portuguese is spoken. Its use with populations of better socio economical conditions must understimate important aspects of quality of life, especially in the psychological domain.

Questionnaire reduction - It was already expected a great exclusion of items, since the pilot instrument covered all possibilities within each domain, making them extensive. The fact that many questions of validated instruments were excluded is understandable. Translation, simplification and utilization out of the original domain context turns the items into new ones, with new psychometric prop e rties that should be tested ${ }^{39}$ again. The frequency of endorsement was the statistical technique that excluded the greater number of items. The low number of intractable epilepsy patients must turned answers to a more positive direction. In discard ing these questions, it was intended to make the instrument a more discriminative one. There was a significant diff e rence between groups of seizure contro I in the physical domain and total score (Tables 1 and 2). The other domains showed a trend to difference, which could be proved with a large sample. Information of the total score is dubious, since mixing diffe rent domains information makes little sense. Homogeneity of pilot domains was good, as measured by Cronbach's alpha and total-item correlation (Table 3). Reduction affected social and familiar domain homogeneity. We tried to mix social and familiar items in a unique domain, but alpha continued below 0,70 . The excellent alpha of the psychological and cognitive domains allowed us to lower question numbers by qualitative means, making the final questionnaire shorter.

The final instrument (QVCE-50) - QVCE-50 maintained good homogeneity in the same domains, and criteria validity was attainable only in the physical domain. The lower number of respondents did not permit validity conclusions with the sample. It will be necessary a new and bigger sample to retest criteria validity and to test reliability.

In conclusion, QVCE-50 is a promissing Brazilian 
HRQL questionnaire for children with epilepsy. This new perception of health and disease opens a perspective of a more efficacious and individualized treatment for epileptic children. The next step is to retest QVCE-50 psychometric properties with a bigger sample. It may be necessary to rebuild the social and familiar item. We intend to test reliability with test-retest. Other functions of the instrument that must be analyzed are changes in quality of life in time and specific treatments.

Acknowledgments - We thank Professor Ronir Raggio Luiz (Bioestathistics NESC/UFRJ) for suggestions and help in the statistical planning; Dr. David Streiner (Kunin-Lunenfeld Applied Research Unit, Universidade de To ronto, Canada) for the valuable insights into health scale construction methodology; Drs. Gus A. Baker (Walton Hospital, Liverpool, United Kingdom), Hans A. Carpay (Westeinde Hospital, Hague, The Netherlands), Orrin Devinsky (New York University), Peter Hoare (Royal Hospital for Sick Children, Edimburgh, United Kingdom), and Mark Sabaz (New South Wales University, Kensington, Australia) for authorizing the utilization of items of their instruments and Dr. Maria Antônia Serra-Pinheiro for paper review. Professionals interested to receive a copy of QVCE-50 for analysis, please contact Dr. Heber Maia (heber@redetaho.com.br)

\section{REFERENCES}

1. Guyatt GH, Feeny DH, Patrick DL. Measuring health-related quality of life. Ann Intern Med 1993;118:622-629.

2. Gortmaker SL, Walker DK, Weitzman M, Sobol AM. Chronic conditions, socioeconomic risks, and behavioral problems in children and adolescents. Pediatrics 1990;85:267-276.

3. Austin JK, Smith MS, Risinger MW, McNelis AM. Childhood epilepsy and asthma: comparison of quality of life. Epilepsia 1994;35:608-615.

4. Maia Filho HS, Gomes MM. Epilepsy in childhood and quality of life. J Epilep Clin Neurophysiol 2004;10:87-92.

5. Maia Filho HS, Gomes MM. Evaluation of the quality of life instruments in childhood epilepsy. J Epilep Clin Neurophysiol 2004;10:147-153.

6. Baker GA, Jacoby A, Smith DF, Dewey ME, Chadwick DW. Development of a novel scale to assess life fulfillment as part of the further refinement of a quality-of-life model for epilepsy. Epilepsia 1994;35:591-596.

7. Cramer J, Perrine K, Devinsky O'Bryant-Comstock L, Meador K, Hermann B. Development and cross-cultural translations of a 31-item quality of life in epilepsy inventory. Epilepsia 1998;39:81-88.

8. Devinsky O, Vickrey BG, Cramer J et al. Development of the quality of life in epilepsy inventory. Epilepsia 1995;36:1089-1104.

9. RibeiroJL, Mendonça D, Martins da Silva A. Impact of epilepsy on QOL in a Portuguese population: exploratory study. Acta Neurol Scand 1998; 97:287-294.

10. Alvarado L, Ivanovic-Kuvic F, Candia X, Méndez M, Ibarra X, Alarcón J. Psychosocial evaluation of adults with epilepsy in Chile. Epilepsia 1992;33:651-656

11. Chaplin JE, Yepez R, Shorvon S, Floyd M. A quantitative approach to measuring the social effects of epilepsy. Neuroepidemiology 1990;9:151-158.

12. Curral R, Palha A. Um estudo para validação duma versão portuguesa do WPSI. J Bras Psiquiatr 1996;45:625-632.

13. Gilliam F, Kuzniecky R, Faught E, Black L, Carpenter G, Schrodt R. Patient-validated content of epilepsy-specific quality-of-life measurement. Epilepsia 1997;38:233-236.

14. Mihara T, Inoue $Y$, Matsuda Ket al. Recommendation of early surgery from the viewpoint of daily quality of life. Epilepsia 1996;37(Suppl.3):S33-S36.
15. Pal DK. Quality of life assessment in children: a review of conceptual and methodological issues in multidimensional health status measures. J Epidemiol Com Health 1996;50:391-396.

16. Guerreiro MM, Silva EA, Scotoni AE, Souza EAP. Qualidade de vida em epilepsia na infância. JLBE 1994;7:21-26.

17. Batzel LW, Dodrill CB, Dubinsky BL, et al. An objective method for the assessment of psychosocial problems in adolescents with epilepsy. Epilepsia 1991;32:202-211.

18. Carpay HA, Vermeulen J, Stroink H et al. Disability due to restrictions in childhood epilepsy. Dev Med Child Neurol 1997;39:521-526.

19. Cortesi F, Giannotti F, Ottaviano S. Sleep problems and daytime behavior in childhood idiopathic epilepsy. Epilepsia 1999;40:1557-1565.

20. Lewis MA, Hatton CL, Salas I, Leake B, Chiofalo N. Impact of the children's epilepsy program on parents. Epilepsia 1991;32:365-374.

21. Mitchell WG, Scheier LM, Baker SA. Psychosocial, behavioral and medical outcomes in children with epilepsy: a developmental risk factor model using longitudinal data. Pediatrics 1994;94:471-477.

22. Sabaz M, Cairns DR, Lawson JA, Nheu N, Bleasel AF, Bye AME. Validation of a new quality of life measure for children with epilepsy. Epilepsia 2000;41:765-774.

23. Souza EAP, Nista CR, Scotoni AE, Guerreiro MM. Sentimentos e reações de pais de crianças epilépticas. Arq Neuropsiquiatr 1998;56:39-44.

24. Cramer JA, Westbrook LE, Devinsky O et al. Development of the quality of life in epilepsy inventory for adolescents: the QOLIE-AD-48. Epilepsia 1999;40:1114-1121.

25. Fernandes PT, Souza EAP. Inventário simplificado de qualidade de vida na epilepsia infantil: primeiros resultados. Arq Neuropsiquiatr 1999; 57:40-43.

26. Hanai T. Quality of life in children with epilepsy. Epilepsia 1996;37(Suppl 3):S28-S32.

27. Hoare P, Russel M. The quality of life of children with chronic epilepsy and their families: preliminary findings with a new assessment measure. Dev Med Child Neurol 1995;37:689-696.

28. Bruck I, Antoniuk SA, Spessatto A, et al. Qualidade de vida em epilepsia: relato preliminar de 26 adolescentes. Braz J Epilep Clin Neurophysiol 2000;6:193-196.

29. Baker GA. The Liverpool quality of life questionnaire. In Trimble MR, Dodson WE (eds). Epilepsy and quality of life. New York: Raven Press,1995:267-280.

30. Baker GA, Brooks J, Buck D, Jacoby A. The stigma of epilepsy: a European perspective. Epilepsia 1999;41:98-104.

31. Long CG, Moore JR. Parental expectations for their epileptic children. J Child Psychol Psychiatry 1979;20:299-312.

32. Austin JK, Huster GA, Dunn DW, Risinger MW. Adolescents with active or inactive epilepsy or asthma: a comparison of quality of life. Epilepsia 1996;37:1228-1238.

33. Austin JK, Huberty TJ, Huster GA, Dunn DW. Academic achievement in children with epilepsy and asthma. Dev Med Child Neurol 1998; 40:248-255.

34. Seidenberg M, Beck N, Geisser M, et al. Academic achievement of children with epilepsy. Epilepsia 1986;27:753-759.

35. Gill TM, Feinstein AR. A critical appraisal of the quality of quality-oflife measurements. JAMA 1994;272:619-626.

36. Comission on Classification and Terminology of the International League Against Epilepsy. Proposal for revised clinical and electroencephalographic classification of epileptic seizures. Epilepsia 1981;22:489-501.

37. Comission on Classification and Terminology of the International League Against Epilepsy. Proposal for revised classification of epilepsies and epileptic seizures. Epilepsia 1989;30:389-399.

38. American Psychiatric Association. Diagnostic and statistical manual IV (Portuguese translation). Porto Alegre Artes Médicas 1994.

39. Streiner DL, Norman GR. Health measurement scales. A practical guide to their development and use. Oxford: Oxford Univ Press: 1989.

40. Perrin EC, Sayer AG, Willett JB. Sticks and stones may break my bones... Reasoning about illness causality and body functioning in children who have a chronic illness. Pediatrics 1991;88:608-619.

41. Perrin EC, Gerrity PS. There's a demon in your belly: children's understanding of illness. Pediatrics 1981;67:841-849.

42. Bibace R, Walsh ME. Development of children's concepts of illness. Pediatrics 1980;66:912-917.

43. Epstein AM, Hall J, Tognetti J, Son L, Conant L. Using proxies to evaluate quality of life. Medical Care 1989;27(Suppl.3):S91-S98. 